International Journal of Humanities and Social Sciences.

ISSN 2250-3226 Volume 11, Number 1 (2021), pp. 7-15

(C) Research India Publications

https://dx.doi.org/10.37622/IJHSS/11.1.2021.7-15

\title{
Misogyny in Malayalam Films
}

\author{
Greeshma D. \\ Guest Lecturer \\ Sri Sathya Sai Arts and Science College \\ Thiruvananthapuram, Kerala, India.
}

\begin{abstract}
Malayalam movies are always praised for the complexity of characters and their mesmerising scripts. But many raised voices against the misogyny that is still prevalent in the industry. Actresses have little or no role unless it is a female-centric movie. This condition reflects the deeply rooted gender discrimination and patriarchy in the state which upholds modernity only in the superficial level. Audience imitates their heroes and worships them as demigods. So, it is essential in their part to deliver healthy content. Even today, there is a lack of strong female characters in Malayalam movies, they are only reduced to ornaments and plot devices. Superstars and fans associations rule over the industry. The abduction and rape of a female actress and the response from Association of Malayalam Movie Artists (AMMA) all point out to how male-dominated the industry is. Women in Cinema Collective (WCC), was formed as a response to the misogynous position adopted by a male-dominated organisation of Malayalam cinema. The industry could not accept these strong opinionated as they ridiculed the collective through a satirical skit with superstars and other women actors. The present study would explore the misogyny in Malayalam movies from different aspects.
\end{abstract}

Keywords: Misogyny, WCC, AMMA 


\section{INTRODUCTION}

Subjectivity has been a major concern for Foucault (1981) throughout his philosophical enquiries, and he considers the process of subjectivization as the centre stage in his conception of power. For Foucault (1981), subjectivity is based on the social context and it is constituted through a "game of truth" that is nothing other than the power relations.

Though Foucault's works were chiefly gender-neutral, his conceptions of subjectivity, knowledge, discourse and power could be significantly adapted to theorize female bodies, subjectivity and the patriarchy prevails in different socio-cultural contexts. Criticizing Foucault's gender neutrality, and acknowledging the validity of his power conception, King (2004) propounds that, gender, femininity in particular "is a discipline that produces bodies and identities and operates as an effective form of social control". According to King (2004), even when the feminine lens of power is absent in Foucault's work, the female body itself exemplifies Foucault's conception of discipline and power.

\section{PATRIARCHY IN KERALA}

Kerala, the state which has higher dignity of social development, has also given some paradoxical reports in terms of gender sensitivity and domestic violence. The recent study of the National Family Health Survey (NFHS) proved to be one of such contradictory indicator where the NFHS report says 69 per cent housewives in the state endorse the domestic violence that they face. One of the leading newspapers of the state Mathrubhumi reports that when compared to NFHS 3 result published 10 years back, the number of people who supported domestic violence has increased. In Kerala, 66 per cent women and 54 per cent men were supportive of domestic violence according to the previous survey. In a study on the family structure, women's education and work in Kerala Eapen and Kodoth (2003) perceives that the domestic violence and dowry system in the state indicate the embodied subordination of the women. According to a report published in the official website of Kerala Police, the crime against women in Kerala has been on gradual growth since 2007. In 2007, the total number of rape cases in Kerala was just 500 whereas in 2017 it reached a record statistic of 1807. Similar growth can be seen in molestation and abduction cases. Quoting S Sreekanth, Circle Inspector of Hi-tech cell, The New Indian Express reports, "A minimum of three complaints is being received daily by the 19 cyber cells functioning in the state. This shows the social media abuse against women is soaring by no means. Most of the complaints are related to creating fake profiles and derogatory remarks" (The New Indian Express, Jan 6, 2018). 
The social situation in Kerala is deeply patriarchal and strong gender stereotypes prevail, which prevents freedom, mobility and independence among women. From exploring the female labour force participation in Kerala, we can understand that, the women in Kerala are enjoying better standard in comparison with other regions of the country, but have extremely low participation in economic-related activities.

Analysing the prevailing misogyny in the film industry of Kerala and the patriarchal elements that are deep-rooted in the social system of the state, Meena T Pillai (2017) argues that, despite holding the higher literacy rate, the labour atmosphere in Kerala in different workspaces such as industries, administrative and educational sectors are largely grounded and driven on misogyny. She perceives that the misogyny has been well entrenched in the "religious, social, cultural and political unconscious of the state". The culture industry of the state, especially the film sector is found to be satisfying the male desires both in economic and libidinal terms and thus it has become "a superstructural expression of reified capitalist patriarchy".

Quoting the 68th report of National Sample Survey Office (NSSO), Meena T Pillai (2017) says that female labour participation in Kerala is miserably lagging compared to that of men. While males' labour participation marks the figure of 57.8 per cent, female labour participation is just 24.8 per cent. Meena T Pillai (2017) argues that the state has been witnessing the emergence of new patriarchies with the growing clutches of a market economy where the culture of commodification is an inherent norm. She observes the presence of a network in the Malayalam film industry wherein the superstars become the controllers of different entities inside the industry such as production, distribution, exhibition etc. This network eventually resulted in the formation of an ownership conglomerate which is largely driven by the stars.

\section{MISOGYNY IN MOLLYWOOD FILMS}

Misogyny in Malayalam cinema reflects the patriarchy deeply ingrained in the society of Kerala. On November 7, 1928, JC Daniel achieved his life-long dream by premiering his Vigathakumaran, the first feature film in Malayalam. The screening at Capitol Theatre in Trivandrum was attended by a large crowd. Daniel's delight soon turned upside down as an angry mob pelted the screen. The trigger for this was that the female protagonist PK Rosi, a Dalit Christian played the role of a Nair woman Sarojini in the movie. A Dalit woman who is socially ostracised and deemed spiritually polluting to touch, playing a Nair lady enraged the feudal Nair community. She was abused and attacked and her house was burned down. Fearing her life, the first female heroine of Malayalam film industry had to flee to Tamil Nadu and lead an unknown life to others. 
Malayalam cinema has come a long way. Now after 91 years Malayalam film industry is well-reputed for creating some of the best movies in the country year after year with innovative storytelling and exploration of socially relevant issues. But what about the women or heroines of Malayalam cinema?mIt is yet to get rid of the othering of women on screen.

An evocative scene from a 1986 movie by the gifted director Padmarajan has actor Thilakan, who plays the role of a ruthless stepfather in the movie, tell his stepdaughter's lover, played by Mohanlal, that "now you can take her". The braggart tone is an affirmation that 'I have had her and now you take her'. That statement partially sums up the Malayali male's perpetual fantasy about a woman - that since she had been intimate with him, she is now worthless.

In a film named 'Njangal Santhushtaraanu' (1999) a film about a married couple where the wife is presented as a modern woman who is egoistic and having an aversion towards the culture of Kerala. The film is the best example of the 'kulapurushan' (ideal man) transforming his wife into a kulastree (ideal woman). But in reality, the film portrays a series of incidents where the husband mistreats the wife and calls it his method of 'curing her mindset'.The film seems to justify the husband who humiliates and beats his wife in and even calls out to her gender saying, "Women should be quiet and disciplined". At the end of the film, her father hails him as a "God" just because he decides to marry her despite knowing the truth of her whereabouts. This film was hailed as a family entertainer and was even a super hit back in its day. This is a notable pattern in pre-2000s Malayalam cinema. Women who wear modern clothes, speak English, and raise their opinion in front of anyone without fear are portrayed as arrogant, selfish and will be redeemed by the hero. Finally, she will be transformed into the 'kulastree' avatar wearing traditional saree and apologising for her 'sins'.

Using femininity as an insult is another common trait in Malayalam movies. In the super hit Malayalam film, 'The Truth' Mammooty enacts a scene where he says "nee verum pennannu" (transl: "You are only a woman") to a character played by Vani Viswanath.

This dialogue was applauded and cheered by young men who idolized Mammootty. This dialogue became so popular that even in real life it is used to silence women. There were viral memes of this dialogue. Films like 'Athirathan'(1984) and 'Nadanpennum Naatupramanimarum'(2000) also portrays similar dialogues.

The 2016 film 'Kasaba', became a point of huge controversy in the state. In the film, Mammootty, plays a policeman and he threatens a female officer saying "I can stop your menstrual cycle if I would like to". The controversy began after actress Parvathy 
spoke about this demeaning scene at a film festival in Kerala. She had said that it had been disappointing to ascertain an actor par excellence enacting scene that insults women. She was speaking against the glorification of misogyny in Malayalam films. Parvathy had to face cyber-attacks and even rape threats. Young men, who continue to run fans clubs, replicate dialogues and imitate their heroes and are likely to identify with and propagate these dialogues.

The Romanticisation of Stalking and Molestation is quite common in Malayalam films even in the films of superstars. In a film named 'Kelkatthe Shabdham', Mohanlal plays Babu, a sex addict who stalks Jayanti (Ambika) who was his ex-lover, saying "I won't leave you alone“. Another movie, 'Vandanam', too features a hero stalking a heroine because of the central plot. Years later, in CID Moosa' (2003) Dileep plays Sahadevan, an aspiring policeman who falls crazy with Mina (Bhavana) and stalks her. She loses her job due to his continued stalking. When she confronts him, he replies "I won't leave you alone. I will love you, cause you to pregnant and destroy your youth. Finally, you beg for water from me. You wait and watch," walking away heroically. This dialogue generated laughter and applause from men. But women were terrified by men who can't take "no" for an answer. When movies romanticise stalking and such unhealthy behaviour as normal, many men get inspired by them in real life. Stalking is a serious crime against women. Though many don't even realize it as it is portrayed romantically by the actors the fans seem to idolise.

Majority of the Malayalam movies portray a girl as one born and raised for the sole purpose of marriage. The sisters or daughters are presented as a burden and liability upon the family. The hero works tirelessly to get her married off. No one seems to bother about what she wants. The movie 'Oppam' (2016) features a man betraying his best friend to a serial killer because the latter offered to give him a lot of money. $\mathrm{He}$ tries to justify the same with "I have 2 daughters". In 'Bhagyadevatha' (2009), starring Jayaram the husband Benny(Jayaram) tortures and humiliates his wife Daisy (Kaniha) because she does not give him a dowry. He learns his lesson when his sister needs to be married off and needs dowry urgently. The best way in which a lead character can earn sympathy from the audience is by having unmarried sisters or daughters.

The movies also normalise sexual harassment done by heroes calling it 'love'. Mahayanam(1989) and Kanmadam(1998) portray such scenes. Sexual assault and violence against women have been used as a weapon by most villains to silence freethinking women characters. In, 'Lion' (2006) Kavya Madhavan's character Shari is forced portrayed as a "raped woman" by a goon because as per the social mindset being "raped" is worse than "raping". Casually, she is termed "aa sadhanam" (that thing). Even the mother of the survivor then goes on to say that her life is ruined, she 
is stained and destroyed. Objectification of rape survivors and portraying them as 'withered flowers' or as 'destroyed vessel beyond repair.' It is presented as though the dignity of a woman resides in her vagina and that her life is over if she is raped. This actually reflects the common mentality of the society we live in. 22 Female Kottayam' is a movie breaking away from the normal narrative where Tessa Abraham (Rima Kallingal) fighting back at her rapists. However, she keeps repeating, "I am stained", "I am impure" and "My life is ruined". She says that she will never be the same person. The film Puthiyaniyamam, featuring Nayantara as a rape victim Vasuki who fights for justice. The movie strongly campaigns for the death penalty of rapists and the need for such punishment against rape. But the film's strong female character ends up propagating an anti-feminist view by calling herself an 'impure vessel'. As long as this cringe-worthy objectification and victimization happen, rape survivors do not get justice.

Malayalam movies are generously adopted to silence women in real life. It is as though the whole male movie fraternity - writers, directors, actors and all - had been racking their brains and juicing their creativity only to run down women. Dialogues like "pennu pennite sthaanathirikkanam" (transl: "a woman should remain in her place") and "pennayal adakkavum othukkavum venam" (transl: "women should be quiet and disciplined") are common and are mostly uttered by heroes who themselves abuse and stalk women. Odd as it may sound, careers have been built over it. Female bashing is an industry by itself, and no so-called Malayalam superstar can escape blame. A raft of films with male chauvinists in lead roles has been box-office hits even as recently as a few years ago, prompting producers to make sequels and prequels. Of course, changes are visible now with young men and women coming together to question the status quo and alter the narrative, to ring out the old and bring in the new.

Heroes are worshipped to an extent that there are fans associations, statues and even temples in their names. Audience imitates their heroes and worships them as demigods. So, it is essential in their part to deliver healthy content. Even today, there is a lack of strong female characters in Malayalam movies. They are only reduced to ornaments and plot devices. The audience ought not to be ignored in the creation of art and film.

A few years back renowned Malayalam actor was kidnapped and molested inside a moving car. She went through all the atrocities a survivor has to face in this society, from being victimised by the media who revealed her name to shaming by the audience. Though the whole industry came forward to support her at first and the accused men were caught by the police and government ensured changes in terms of women's safety. But when a superstar was arrested as the prime mastermind 
regarding the case the response from AMMA clearly shows how male-dominated the industry is.

Women are denied autonomy and mobility in the name of "safety". A woman being raped if she stays out late at night is seen as a "normal" phenomenon. Thankfully, a lot of women are calling this out today. The highlight of this incident is that the actor, while fighting vehemently for justice, also chose to go back to acting. This is an enormous statement to beat this society who shamelessly promoted rape culture. Actor Prithviraj took to Facebook to applaud her decision and while doing so, he made a statement: "COURAGE_LSOME OF THE MOST POIGNANT MOMENTS IN MY LIFE HAVE BEEN PUNCTUATED WITH MOMENTS OF INCREDIBLE..."

Since misogyny has been glorified for an extended time in Malayalam, his statement makes an excellent deal of difference. Actress Manju Warrier applauded him for the same. Prithviraj's films have had several misogynist undertones. In the movie"chocolate" Prithviraj's character, Shyam misbehaves with Ann enacted by Roma. He even goes to the extent of saying that he will impregnate her and that she won't be free for ten months. Prithviraj's statement makes one reflect on the extreme misogyny prevalent in Malayalam cinema - both in his older films also as generally.

The Women in Cinema Collective or WCC, as it is popularly called was formed as a collective for ladies artists belonging to the planet of Malayalam cinema - singers, actors, directors all included. The collective shaped itself last year after the brutal attack on the lady actor, shocking the sensibility of the people of Kerala. The decision to make a collective of this type was a response to the misogynous position adopted by a male-dominated organisation (AMMA) of Malayalam cinema that was established within the year 1985 .

AMMA as it is popularly known, Association of Malayalam Movie Artists, according to their website, is meant to provide a professional platform for open and healthy discussions and provide care and protection to its members. The double standards of this industry were revealed when the attack was later exposed to have been plotted by another leading male actor and he was taken into custody and his bail application rejected thrice. AMMA, as an organisation, as a collective, refused to adopt a firm stance against the male actor and preferred to gloss over the violent attack on the actor.

The Malayalam film industry even attacked the Collective, by presenting a short drama at the programme organized by AMMA, titled AMMA Mazhavillu (Rainbow). The drama was titled 'Women Empowerment: Inaugural Ceremony of the Collective'. The short play had superstars and a few women actors donning the roles of the 
women artists who had dared to form the collective. The barbs were thinly veiled; the sarcastic comments and observations intended to belittle the efforts of the women and the script with very little humour and that in bad taste.

Every character was stereotyped, and the women were revealed to be hypocritical and weak, shallow and ridiculously stupid. Endorsing male domination through various dialogues and incidents, the play progresses, with superstars acting out their parts as irresistible alpha males, their maleness emphasised through dance moves and songs by the women characters. The women are depicted as inherently vain; typical of every female character ever populated the screens during the glorious years of the superstars. The short play affirms the fear and insecurity of the patriarchal hegemonic powers that have been ruling the world of Malayalam cinema and the resistance the Collective seems to be putting up against them.

Women in Malayalam cinema isn't a Northern Alliance, the ladies who resist and rebel are only a couple of them. Yet their voice sounds loud and clear and the WCC as a collective seems to have travelled far within a few years. WCC has been actively intervening in issues but the AMMA has not missed a single opportunity to mock them and the social media users also play an active role in trolling even threatening few actresses in a derogatory manner. Irrespective of all these WCC still abide by their beliefs and strong desire to erase misogyny from movies. They also demand for a secure work environment for actresses and equal pay.

Their responses are organic and rational, resorting to asking sensible questions that challenge the positions and narratives of the privileged. The threat this collective presents to male domination is very real and every act of violence, both virtual and real, seems to empower them and strengthen them in their struggle for dignity and equality in workspaces.

\section{CONCLUSION}

Kerala with its admirable social development indices and therefore the huge female workforce is increasingly being revealed as a misogynous society, deeply entrenched in patriarchal social structures. Malayalam cinema reflects the complex social reality of embracing modernity outside yet remaining patriarchal and male-dominated in the confines of domestic space. Malayalam movies are praised that they resound the complexities of the human mind. Malayalam movies have visually communicated socio-political problems with the mass audience. These movies have given an area for brand spanking new trends in narration and performance. Within the midst of changes in Mollywood, one thing remains same that's the mockery of female representation in Malayalam movies. Gender discrimination is often in terms of verbal abuse, violence, 
humiliation or intimidating behaviour conduct. In this way, Malayalam movies are advocates of gender discrimination. Malayalam movies reach to a wider audience so when it comes to its representation of women, the Malayalam industry needs a reality check. Viewers of Malayalam movies are still male-dominated and therein young males form the greater part. Entertaining the male youth, this is often most likely the primary thing that comes into the mind of filmmakers. So they add intense sexuality and vulgarity in movies.

Malayalam movies are generously adopted to silence women in real life. Dialogues glorifying misogyny are mostly uttered by heroes who themselves abuse and stalk women. Odd as it may sound, careers have been built over it. Female bashing is an industry by itself, and no so-called Malayalam superstar can escape blame. A raft of films with male chauvinists in lead roles has been box-office hits even as recently as a few years ago, prompting producers to make sequels and prequels. Of course, changes are visible now with young men and women coming together to question the status quo and alter the narrative, to ring out the old and bring in the new.

\section{WORKS CITED}

Eapen, M \& Kodoth, P. (2002), Family structure, women's education and work: Re-examining the high status of women in Kerala. Centre for Development Studies, Trivandrum, India, Centre for Development Studies

Foucault, M. (1981), The Order of Discourse

King, A. (2004), The Prisoner of Gender: Foucault and the Disciplining of the Female Body. Journal of International Women Studies,5(2).

Pillai, M. T. (2017), The Many Misogynies of Malayalam Cinema. Economic and Political Weekly,L II(33). [Online] Web Assessed on 7 Mar 2020 
